\title{
Environmental Management of the Islamic Perspective
}

\author{
Ara Hidayat and Hary Priatna \\ Faculty of Tarbiya and Teacher Training \\ UIN Sunan Gunung Djati Bandung \\ Bandung, Indonesia \\ arahidayat@uinsgd.ac.id, harypriatna@uinsgd.ac.id
}

\begin{abstract}
Environmental problems are currently inevitable. The problems are amplified by low level of public awareness about environment and the ever-increasing level of environmental damage done by irresponsible people. Education plays an important role in changing people's paradigms about environment. People need to be made aware of the importance of their environment. In this regard, madrasa can be an ideal means to raise public awareness of the importance of environmental preservation and management. This research was carried out using a descriptive naturalistic method. Data were collected by means of interview, questionnaire, and observations. The research found that there were many ways implemented in madrasa to instill environmental awareness so as to realize the environmentally-sound madrasa.
\end{abstract}

Keywords-environment; fiqhul bi'ah; islam; madrasah; management

\section{INTRODUCTION}

The issue of environmental damage has been under the world's spotlight. The global warming has resulted in the increase of number of disasters and extreme climate change. WHO suggest that environmental factors are very critical for people's health and welfare. Fereidoun says that environmental pollution has been a global problem and is very potential to affect people's health. Pollution in dense urban industrial centers in developed countries has been reaching a very worrying point. In under-developed countries, more than $80 \%$ polluted water is used for irrigation with only $70-80 \%$ food and living security in urban and semi urban areas [1].

Based on FAO data in 2010, the world's forests, including Indonesia's forests, store 289 gigatons of carbon that play an important role in maintaining climate stability. Ironically, based on data from The Ministry of Environment and Forestry, Indonesia's forests have been reduced to approximately 130 million hectares or shrinking at least 1.1 million hectares each year and 42 million hectares are cut down [2]. The biggest threats to forests in Indonesia are illegal logging, forest conversion, forest fires and massive exploitation. This frequently leads to space conflicts between wildlife and humans due to the disruption of forest ecosystems.

Environment is everything that is around us. Man and nature should be complementary. As the nature of human creation is to become khalifa upon the earth one of whose responsibilities is to preserve the nature as the provider of needs of all human beings. But it is their greed that causes the environmental damage despite that they have been warned not to make any. Islam declares the command of preserving nature implicitly and explicitly, for example in Sura al-Araf Aya 85 on environmental preservation, al-Baqara Aya 205 on environmental damage by the hypocrites, al-Anam Aya 165 on humans being khalifa to preserve environment. Islam, as a religion that not only regulates human relation with God but also human relationships with other creatures, actually has a normative basis both implicitly and explicitly about environmental preservation. In summary, Islam has a very special thing to offer to the world to prevent the multifaceted environmental crisis. We believe that the environmental crisis is a moral one. Islam provides very efficient ethical principles to deal with the environmental crisis. The essence of such Islamic based environmental ethics is that all the resources upon which life depends have been created by God as a Trust (amana) in our hands. Man, the vicegerent (khalifa) of God on earth, is only a manager of resources not a proprietor, a beneficiary and not a disposer [3].

Today's environmental issue (water, soil, air, and climate) is already at a very worrying state; however, pollution and environmental damage has been dealt with a business-as-usual approach. A new breakthrough is required [4].

Experts point out three main factors that cause environmental damage:

- Issues related to the way of humans view themselves, nature, and their stance in an ecosystem.

- Economic and political issues, characterized by the abundance of polluting industries

- Religious misunderstanding that every disaster that happened is the will of God and that people do not take part in them [4].

The paradigm change especially in education is believed to be a necessity taking into account the development of environmental sophistication and as a strategic-ideological effort to improve understanding which in turn can form a new awareness that can encourage them, both as individuals and a group, to maintain the ecological balance [2]. It is also important to emphasize a pro-environment vision in the 
mobilization of individuals. Thus, an environmental leadership that can influence individuals and mobilize organization to realize a long-term ecological sustainability vision can be established [5]. Bernauer and Betzold assert the need for potentially positive civil society involvement in order for research on environment to have policy implications [6]. The effort to raise people's awareness needs to be encouraged in order to prevent natural damage. God created human beings as khalifa, but it does not mean that they are free to exploit the nature without taking into account the ecological balance. In this case, education is deemed and believed to be an ideological strategic instrument to realize a civilized and environmentallysound society.

The purpose of this study is to analyze school management to bring about an environmentally-sound generation, in this case specifically how the schools instill students' awareness about their environment. The study was conducted in all madrasa aliyas (Islamic senior high schools) in the City of Bandung. Data were collected through interviews, questionnaire, and observations focusing on the following aspects:

- Schools' environmental visions and missions

- Teachers' commitment on the realization of the schools' visions and missions

- Teachers' methods in instilling environment-related Islamic values

\section{LITERATURE REVIEW}

This paper discusses fiqh al-biah (Islamic environmental law), human role in the environmental conservation in the perspective of Islam, and madrasa management to realize environmentally-sound education.

\section{A. Environment}

Environment is actually of biological, non-biological, and social, both natural and artificial. Sayyid Muhammad Al Husaini as Syairazi points out that environment is generally defined as everything related to humans except humans themselves [2]. Environment has significant influence on the sustainability of human beings and other living things' lives. Human beings always interact with the environment in which they live [7]. Environmental science can be defined as a science that studies the reality that occurs in the environment, how to manage it in order to maintain the sustainability of life and welfare of humans and other living creatures [2].

\section{B. Fiqh al-Biah}

Environment is called al-Biah in Arabic. The Islamic environment jurisprudence is called fiqh al-biah, which is a constructive framework of Islamic law in understanding the natural environment, both macrocosm and microcosm [4]. The term figh, according to Muhammad bis Yaqub al fayrus Abadi, etymologically means knowledge about everything. Terminologically, according to Jamaludin Abdurrahim bin Hasan Al-Asnawi, figh is the study of practical sharia laws derived from detailed daleels [2].
Fiqh is an Islamic law system. It always talks about rules of everything in relation with human life in a detail and specific manner. When it comes to environment, figh discusses things like environmental issues and principles of environmental conservation. Basically, figh is a factual and detailed description of Islamic teaching values derived from the Quran and Sunnah. These values are continuously studied by experts in the field who are really aware of the development, needs, and welfare of people and of environment [4]. According to Hasan Hanafi, figh al-biah requires the revitalization of usul alfiqh (principles of Islamic jurisprudence). Fiqh is practical study, and usul al-figh is the theorization of acts, logics, and praxis methodology. The revitalization of usul al-figh is expected to reestablish figh upon its fundamental foundation; that is, problems [7].

Understanding about fiqh al-biah and environmental conservation efforts needs to be laid upon a strong moral foundation to help deal with environmental damage. Fiqh albiah encourages those who claim to be the believers to take responsibility for their surrounding environment and to convince them that environment is the Trust God offered to them. Education has a significant influence on individual moral and knowledge formation. Islamic educational institution (madrasa) is expected to bring about generation committed to the environmental conservation with reference to the Quran and Hadiths.

\section{The Role of Human Beings in the Environmental Conservation in the Islamic Perspective}

In the perspective of Islam, humans are the settlers in their environment as stated in Sura Hud Aya 61 which reads "He has produced you from the earth and settled you in it." This is where humans play their role as the thinking animals to contextualize religious teachings in environmental affairs. The term earth is mentioned 485 times with the same reference and context [2]. In addition to the aforementioned Aya, it is said in Sura al-Baqara Aya 30 that humans are khalifa on earth. Another Aya supporting this is Sura al-Jathiya Aya 13 which reads "And He has subjected to you whatever is in the heavens and whatever is on the earth - all from Him. Indeed in that are signs for a people who give thought." It goes to show that every happening on earth cannot be separated from human morals, cultures, and actions.

\section{Management of Environmentally-Sound Education}

The results of studies in madrasa aliyas in Bandung show that some madrasas explicitly states environment-related missions, some implicitly. An example of explicitly stated environment-related mission reads "to create an educational, cultured and clean madrasa environment."

The implementation of madrasas' visions and missions were analyzed with reference to the Regulation of the Minister of Environment of Republic of Indonesia Number 5 of 2013 on the Implementation Guidelines for Adiwiyata (Green Schools) Program [2]

- Environmentally-sound policy with the following standards: (a) the School-Based Curriculum (KTSP) consists of environmental conservation and 
management efforts and (b) School Annual Working Plan Budget (RKAS) consists of environmental conservation and management efforts.

- The implementation of environment-based school with the following standards: (a) teachers are competent to develop environmental instructional activities and (b) students learn about environmental conservation and management.

- Participation-based environmental activity with the following standards: (a) implementing environmental conservation and management activities for the school society and (b) establishing partnership with among others society, government, private sectors, media, and other schools as an environmental conservation and management effort.

- Management of eco-friendly facilities with the following standards: (a) the availability of eco-friendly facilities and infrastructure and (b) the improvement of the eco-friendly facilities and infrastructure at school environment.

The results of analysis show that generally madrasas have developed environmentally-sound policies, have competent teachers, sufficient facilities, and carry out participation-based environmental activities such as Picking Up Trash Movement (GPS) every Monday, Wednesday, and Friday in one of public madrasa aliyas in Bandung. Based on data collected through interviews, questionnaires, and observations, the realization of environment-related vision and mission not only depends on natural science teachers' commitment, but also all school society members. There are many methods in instilling environment-related Islamic values; among others are assigning task of making simple ecosystem model, observing happenings in the surrounding environment like flood, assigning a trash recycling project, and so on. The questionnaires reveal that such activities have positively raised students' awareness.

\section{CONCLUSION}

Based on the results of the research, it can be concluded that there are many ways the teachers take to instill environment-related Islamic values. The school's vision and missions are very critical for the realization of environmentally-sound madrasa to bring about a generation with capabilities, knowledge and understanding of environmental management and conservation. The indicator that environmental management in Islamic educational institutions is effective is the synergy between different parties who are equally committed to implementing environmental management and conservation in accordance with Islamic teachings. Another indicator is the increased awareness of the students in understanding human responsibility to the environment and can apply it in everyday life. This study provides a new picture of Islamic educational institutions that sustain the environment.

\section{REFERENCES}

[1] A.M. Khan and A.M. Ghouri, "Environmental Pollution: its effects on Life and Its Remedies," J. Arts, Sci. Commer., vol. II, no. 2, pp. 276 285, 2011.

[2] A. Hidayat, "Pendidikan Islam dan Lingkungan Hidup," J. Pendidik. Islam, vol. IV, no. 2, pp. 373-389, 2015.

[3] M.Y. Gada, "Environmental Ethics in Islam: Principles and Perspectives," World J. Islam. Hist. Civiliz., vol. 4, no. 4, pp. 130-138, 2014.

[4] M.H. Zuhdi, "Fiqh al-Bî'ah Tawaran Hukum Islam dalam Mengatasi Krisis Ekologi.," Al-'Adalah, vol. XII, no. 35, pp. 771-784, 2015.

[5] O. Boiral, M. Cayer, and C.M. Baron, "The action logics of environmental leadership: A developmental perspective," J. Bus. Ethics, vol. 85, no. 4, pp. 479-499, 2009.

[6] T. Bernauer and C. Betzold, "Civil Society in Global Environmental Governance,” J. Environ. Dev., vol. 21, no. 1, pp. 62-66, 2012.

[7] Syarifudin, "Pencemaran Lingkungan Dalam Perspektif Fiqh," Huk. Islam, vol. XIII, no. 1, pp. 40-63, 2013. 